\title{
Apresentação: literatura além do livro
}

\author{
Presentation: Literature Beyond the Book \\ Presentación: la literatura más allá del libro \\ Diego J. Bustos* \\ Marguerite Itamar Harrison**
}

\begin{abstract}
O interesse pelo assunto da literatura além do livro não é novo. Talvez a penúltima iteração do motivo seja produzida pela chegada da mídia digital décadas atrás, determinando o surgimento de visões críticas sobre as possibilidades do literário além de seus limites históricos. Sabe-se também que não houve vanguarda literária recente em ambos os lados do Atlântico que não seja identificada com uma mudança de coordenadas que envolva uma reinterpretação do campo. Nesse sentido, o Brasil é rico em experiências, sendo o mais relevante o movimento antropofágico da primeira parte do século XX. Então, qual é o significado específico de uma questão especial sobre o "além do livro" no contexto brasileiro contemporâneo? Talvez a resposta mais óbvia seja que as transformações que o país experimentou durante a primeira década do século XXI determinaram um contexto em que o trabalho literário precisava ser repensado, estabelecendo outras direções e caminhos de interpretação. Isso é indubitavelmente verdadeiro e, é claro, determina a intenção analítica da atual coleção de artigos. No entanto, essa resposta, embora precisa, é limitada. Como organizadores deste dossiê, não poderíamos deixar de ver o desafio da curadoria também como uma oportunidade de intervenção no que podemos chamar de tradição da reinvenção: aquela em que o questionamento sobre a literatura está no DNA cultural do país desde a sua vida republicana. O Brasil, metonímia da América Latina, é um território que foi antes de tudo uma história. E uma edição crítica sobre o tema da literatura além do livro é uma oportunidade única de se inserir no contexto de uma longa tradição de análise sobre esse assunto e de tomar o pulso da narrativa literária em uma época em que as narrativas molduram o sentimento do público e a política permeia o domínio criativo. Onde, em resumo, a questão da cidadania é inseparável da cultura.
\end{abstract}

Os trabalhos publicados na seção temática deste número da revista Estudos de Literatura Brasileira Contemporânea demonstram isso, por meio de uma seleção que comenta sobre os diferentes universos nos quais o campo literário brasileiro foi transformado nos últimos anos. Poemas visuais, tridimensionais e interativos; diálogos intertextuais; espaços performativos; prática coletiva e cultura participativa; representações digitais; intervenções socioculturais; estratégias de reclamação de direitos; laboratórios de democracia; políticas de inclusão. Esta lista sugere algumas das manifestações que testemunhamos neste volume. Nosso interesse por esta temática vem de um ponto em comum em nossas pesquisas: os saraus e slams de poesia. Nesses espaços culturais e populares se encontram novos meios de articular a literatura, seja por meio de convivências performativas e participativas, seja por uma ênfase no coletivo e público. No que diz respeito a essas novas tendências literárias, o que vale a pena salientar é a importância que trazem para questões de cidadania e inclusão, ao registrar uma "democratização do acesso à produção poética" (Medeiros, 2018). Analisamos esses espaços culturais tendo em mente a definição que Leila Lehnen (2013) dá para cidadania no sentido amplo da palavra, que abrange o cultural, assim como as dimensões civil, política e social. No Brasil, as transformações econômicas dos primeiros anos do século XXI, coincidentes com o chamado boom das "commodities" e as políticas públicas do governo do Partido dos Trabalhadores, ocasionaram uma situação-limite determinada pelo que Evelina Dagnino (2005,

\footnotetext{
* University of New Mexico, Albuquerque, NM, Estados Unidos.

orcid.org/0000-0003-2271-9094. Email: dbustosd@unm.edu

${ }^{* *}$ Smith College, Northampton, MA, Estados Unidos. Dorcid.org/0000-0003-3474-3825. Email: mharriso@ smith.edu
} 
p. 17) identifica como a perversa coincidência entre "o direito a ter direitos" enquadrado em contextos de exclusão e o projeto de governo neoliberal que busca reduzir a esfera de inferência do estado. Essa coincidência, apesar disso, determinou a emergência duma produção cultural robusta e um correlato crítico onde a cidadania e a democracia estão no centro do debate. Uma das expressões centrais mais férteis que emergiram nessa conjuntura foram os slams e os saraus em sua expressão contemporânea. O interesse do trabalho investigativo dos curadores deste dossiê gira em torno dessas questões, justamente por demonstrar, de acordo com a autora Crystal Leigh Endsley (2016), a importância desses espaços comunitários criativos para a luta pela justiça social. A pesquisa de Harrison, por exemplo, aborda os Slams das Minas por ocuparem um espaço propício na articulação de uma coletividade que concerne ao universo feminino, as pautas feministas e às mulheres da periferia. As diversas participantes dos Slams das Minas dão voz a questões que reclamam as exclusões e a discriminação em termos de gênero da mesma maneira que mostram resistência contra adversidades habituais como a violência doméstica e o assédio sexual. Esses espaços performáticos incentivam, portanto, o ato de protesto contra o machismo, o racismo e a homofobia. A pesquisa de Bustos (representada com um artigo neste número) também segue essa visão, caracterizando o sarau como um espaço onde as aspirações democráticas do país se tornam visíveis, destacando subjetividades e práticas relacionadas à definição da periferia nos últimos vinte anos.

Assim, a partir da interpelação contemporânea do tópico, a ordem que escolhemos propõe uma apresentação tripartida da questão da cidadania na literatura brasileira: novas formas do livro, mundos digitais e novas cidadanias. Embora essa ordem não tenha sido pensada cronologicamente, é significativo observar que o resultado final aponta para uma série de práticas e intervenções que obedecem a dinâmicas históricas: momentos de mudanças e interpelações às definições de cidadania que determinaram a esfera pública nas últimas décadas. Isso permite redescobrir e reinterpretar eventos anteriores à luz dos desenvolvimentos recentes, além de desafiar o contemporâneo como herdeiro de uma tradição de inquietude democrática na cultura do território. Começando com os novos desdobramentos do livro que surgiram durante os anos 1970, revisitando a ampliação dos espaços literários no âmbito da tecnologia e no mundo digital, assim como questionando as novas formas e usos expressivos coincidentes com as transformações democráticas dos últimos anos, o presente dossiê quer apresentar um guia útil para pesquisadores interessados nas ligações entre cidadania e cultura nos últimos anos.

O artigo de Marina Ribeiro Mattar sobre os Poemóbiles de Augusto de Campos e Julio Plaza aproxima o livro ao objeto de arte na maneira como acentua a tridimensionalidade assim como uma estrutura comunicante. Mattar comunica a importância da experiência de articulação do livro-objeto e da questão do simultâneo, que reforça o movimento, o visual e a interatividade.

O artigo de Saulo Gomez Thimoteo trata da adaptação do romance $O$ cortiço como jogo de tabuleiro e do tipo de perguntas que essa adaptação apresenta ao campo literário. Essa tradução dum texto e dum espaço simbólico caro à tradição democrática do país (o tipo de moradia ocupada por trabalhadores que não podem comprar uma casa) revela uma série de gramáticas e reflexões importantes para a compreensão contemporânea do processo democrático brasileiro.

Assim como o anterior, o ensaio de Vinícius Carvalho Pereira comenta mais outra mudança da literatura de sua casa habitual ao estudar o trabalho do artista visual André Vallias e a produção de textos a partir de gráficos e algoritmos 3D. Esse espaço novo, material e simbólico, comenta espaços referenciais fundamentais para a concepção espacial da democracia e suas demandas e desafios, e propõe no processo um guia topográfico das possibilidades democráticas do território e de sua produção cultural.

O ensaio de Manaíra Aires Athayde e de Rejane Cristina Rocha sobre os novos modos de circulação da literatura no mundo on-line a partir dos exemplos de dois grandes escritores brasileiros, Clarice Lispector e Caio Fernando Abreu, reitera o aspecto participativo da cultura no que diz respeito às fanpages nas redes sociais. As autoras enfatizam as experiências vividas no âmbito virtual que permitem uma nova maneira de interpretar e considerar questões de identidade literária. 
O artigo de Daniela Silva de Freitas comenta a relação entre produção poética e cidadania ao historiar o caso do Slam Resistência em São Paulo e a postulação de espaços de democracia a partir da intersecção entre as estratégias formais e temáticas que utiliza. A partir do rastreamento da origem do slam como prática e de seu surgimento na cidade, bem como da análise de textos e estratégias, a autora propõe uma análise das possibilidades cívicas desse espaço.

O ensaio de Paulo Dutra apresenta, a partir da análise do trabalho de Racionais MC's e sua assimilação ao cenário cultural brasileiro, uma crítica analítica aos métodos de branqueamento utilizados pelo discurso acadêmico na discussão do espaço ocupado pela subjetividade afrodescendente no país. $\mathrm{O}$ texto comenta os mecanismos pelos quais esse processo opera e propõe uma discussão sugestiva sobre as maneiras pelas quais as relações entre cidadania e a questão racial servem como pano de fundo dessas dinâmicas.

O ensaio de Diego Bustos sobre os saraus no Rio de Janeiro permitem retomar a questão de cidadania e intervenção cultural ao enfatizar e expandir o espaço cultural para abranger as regiões periféricas. De acordo com Bustos, saraus que integram poesia, música e performance se transformam em laboratórios de democracia que permitem refletir as complexidades geradas em torno de questões como desigualdade, periferia, cultura e empreendimento.

Em resumo, oferecemos aos leitores uma coleção diversificada e consciente da urgência de sua intenção e do espaço que ocupa em um período que parece testemunhar o último ataque ao pleno exercício do direito a ter direitos.

\section{Referências}

DAGNINO, Evelina (2005). Meanings of citizenship in Latin America. Brighton: Institute of Development Studies/University of Sussex.

ENDSLEY, Crystal Leigh (2016). The fifth element: social justice pedagogy through spoken word poetry. Albany; New York: Suny Press.

LEHNEN, Leila (2013). Citizenship and crisis in contemporary Brazilian literature. New York: Palgrave Macmillan.

MEDEIROS, Rosana (2018). Slam das Minas: uma rede de poesia e resistência. Blog do Instituto Brasileiro de Pesquisa e Análise de Dados - IBPAD, 15 fev. Disponível em: https:/ / bit.ly/2RFMu5r. Acesso em: 15 jan. 2020. 